University of Nebraska - Lincoln

DigitalCommons@University of Nebraska - Lincoln

US Army Corps of Engineers

U.S. Department of Defense

2011

Effects of salinity on photosynthesis and respiration of the seagrass Zostera japonica: A comparison of two established populations in North America

Deborah J. Shafer

US Army Corps of Engineers

James E. Kaldy

US EPA, Western Ecology Division, kaldy.jim@epa.gov

Timothy D. Sherman

University of South Alabama

Katharine M. Marko

US EPA, Western Ecology Division

Follow this and additional works at: http://digitalcommons.unl.edu/usarmyceomaha

Shafer, Deborah J.; Kaldy, James E.; Sherman, Timothy D.; and Marko, Katharine M., "Effects of salinity on photosynthesis and respiration of the seagrass Zostera japonica: A comparison of two established populations in North America" (2011). US Army Corps of Engineers. 150.

http://digitalcommons.unl.edu/usarmyceomaha/150

This Article is brought to you for free and open access by the U.S. Department of Defense at DigitalCommons@University of Nebraska - Lincoln. It has been accepted for inclusion in US Army Corps of Engineers by an authorized administrator of DigitalCommons@University of Nebraska - Lincoln. 


\title{
Effects of salinity on photosynthesis and respiration of the seagrass Zostera japonica: A comparison of two established populations in North America
}

\author{
Deborah J. Shafer ${ }^{\mathrm{a}}$, James E. Kaldy ${ }^{\mathrm{b}, *}$, Timothy D. Sherman ${ }^{\mathrm{c}}$, Katharine M. Marko ${ }^{\mathrm{b}}$ \\ a US Army Corps of Engineers, Engineer Research and Development Center, 3909 Halls Ferry Rd., Vicksburg, MS 39180, USA \\ ${ }^{\mathrm{b}}$ US EPA, Western Ecology Division, 2111 SE Marine Science Dr., Newport, OR 97365, USA \\ c Dept. of Biology, University of South Alabama, Mobile, AL 36688, USA
}

\section{A R T I C L E I N F O}

\section{Article history:}

Received 6 January 2011

Received in revised form 21 June 2011

Accepted 24 June 2011

Available online 2 July 2011

\section{Keywords:}

Zostera japonica

Introduced species

Non-native species

Photosynthesis

Salinity

\begin{abstract}
A B S T R A C T
Photosynthetic responses were quantified for two Zostera japonica Aschers. and Graebn. populations from the northern and southern limits of distribution exposed to a range of salinities along the Pacific Coast of North America. Plants were collected from Padilla Bay, Washington (northern) and Coos Bay, Oregon, USA (southern) and cultured together in experimental tanks at 3 salinities (5, 20 and 35) under saturating irradiance for 3 weeks. Subsequently, photosynthesis-irradiance ( $P$ vs. $E$ curves) relationships for leaf segments from the two populations were assessed using an oxygen electrode system. We found no evidence for diel rhythms in either light saturated photosynthesis $\left(P_{\max }\right)$ or dark respiration $\left(R_{\mathrm{d}}\right)$. For the Padilla Bay population, $P_{\max }$ ranged from 192 to $390 \mu \mathrm{mol} \mathrm{O}_{2} \mathrm{~g} \mathrm{DW}^{-1} \mathrm{~h}^{-1}$; for the Coos Bay population $P_{\max }$ ranged from 226 to $774 \mu \mathrm{mol} \mathrm{O}_{2} \mathrm{~g} \mathrm{DW}^{-1} \mathrm{~h}^{-1}$. Photosynthetic maxima of the Coos Bay plants occurred at a salinity of 20 , whereas salinity had no effect on the photosynthetic maxima of the Padilla Bay plants. There were significant differences in leaf tissue $R_{\mathrm{d}}$ among salinity treatments but the two populations responded similarly to salinity. North American populations of Z. japonica are best adapted to intermediate salinities, displaying minimum $R_{\mathrm{d}}$ rates, lower compensation irradiance, higher saturation irradiance, and greater $P_{\max }$ rates at a salinity of 20 . Additionally, the southern population may be better adapted to southward expansion along the Pacific Coast and changes associated with global climate change.
\end{abstract}

Published by Elsevier B.V.

\section{Introduction}

The seagrass Zostera japonica was first reported along the Pacific Coast of North America in 1957 (Hitchcock et al., 1969), and is thought to have been introduced along with oyster seed stock imported from Japan (Harrison and Bigley, 1982). For the last few decades, distribution of this species has been limited to British Columbia, Washington, and Oregon. Within this range, dramatic expansions have occurred in some areas (Posey, 1988; Baldwin and Lovvorn, 1994; Dumbauld and Wyllie-Echeverria, 2003). However, the recent discovery of new populations near Humboldt Bay, California, represents a southward range extension. Harrison and Bigley (1982) suggested that this species had only colonized a small fraction of the available suitable habitat, and that changes in the ecology of the intertidal flats were likely to result from continued spread of this species throughout its potential range. Concerns have been expressed regarding the potential for displacement of the native Zostera marina L. by Z. japonica, and the impacts of this displacement on native ecosystem structure and function (Bando,

\footnotetext{
* Corresponding author. Tel.: +011 541867 4026; fax: +011 5418674049.

E-mail address: kaldy.jim@epa.gov (J.E. Kaldy).
}

2006). Management decisions require information regarding the potential for establishment and spread of introduced species, as well as their potential impacts to native ecosystem structure and function. In the case of $Z$. japonica, these decisions are complicated by the shortage of ecophysiological data available for this species either in its native range or on the American West Coast (Green and Short, 2003).

Although most seagrasses inhabit marine salinity regimes (Tyerman, 1982), several species are reported to be euryhaline (Den Hartog, 1970; Biebl and McRoy, 1971; Ralph, 1998). In addition to the expansion of $Z$. japonica along the coast, there has been an increase in the abundance and distribution across the salinity gradient within estuaries as well. Dudoit (2006) reports that in the South Slough National Estuarine Research Reserve (NERR) in Coos Bay Oregon, $Z$. japonica had moved $3.2 \mathrm{~km}$ upriver from the point of first introduction as reported by Posey (1988). Kaldy (2006) suggested that freshwater seeps may provide a desiccation refuge for $Z$. japonica in the high intertidal. Young et al. (2008) found that the distribution of $Z$. japonica in lower Yaquina Bay increased areal coverage by 400\% between 1998 and 2007. In Yaquina Bay there was substantial spread of $Z$. japonica into many of the less saline slough areas of the lower estuary (Young et al., 2008). Between 2002 and 2009 Shafer and Kaldy (pers. obs.) have noticed that $Z$. 
japonica appeared to occur further upriver in Yaquina Bay. Taken together, this suggests that Z. japonica may be fairly euryhaline and tolerates a wide range of salinities which could affect its ability to colonize potential habitat. Although a wide range of factors control the occurrence and spread of non-native species (including seed viability and dispersal, germination success, predation pressure, etc.), an adequate positive carbon balance is critical for establishment and survival of any plant. Consequently, we focus our initial effort on evaluating how $Z$. japonica photosynthesis responds to large, chronic changes in salinity.

The photosynthetic capability of the seagrass congeners $Z$. marina (see review by Touchette and Burkholder, 2000) and Z. noltii Hornem. (Jiménez et al., 1987; Vermaat and Verhagen, 1996; Plus et al., 2005) have been well studied relative to $Z$. japonica. Several studies have identified diel endogenous rhythms in seagrass photosynthesis, with high rates during morning hours and depressed rates in the afternoon (Libes, 1986; Durako and Kunzelman, 2002; Silva and Santos, 2003). The presence of diel endogenous rhythms could lead to misinterpretation of data; however, the phenomenon has not been investigated in Z. japonica. Previous studies have evaluated the growth and morphological response of several Zostera congeners to chronic salinity changes (Kerr and Strother, 1985; Kamermans et al., 1999; Vermaat et al., 2000; Nejrup and Pedersen, 2008) and short-term photosynthetic responses under hypersaline (>35) conditions (Biebl and McRoy, 1971), but few have examined response to low salinity or longer-term (2-3 weeks) effects of high or low salinity (although see Ralph, 1998). Salinity ranges were on the order of $0-132$ for $Z$. marina and $Z$. muelleri, while salinities of 15 and 35 were used for $Z$. noltii. There are few measurements of $Z$. japonica photosynthetic parameters in general and even fewer in relation to osmotic stress (Ogata and Matsui, 1965).

Huong et al. (2003) suggest that in Vietnam Z. japonica is stenohaline, occurring within the salinity range of 22-32. Based on observed expansions, we hypothesize that $Z$. japonica is more euryhaline than most seagrass species, withstanding salinity fluctuations from about 1 to 34 . We use photosynthetic characteristics as metrics to evaluate its salinity tolerance. The goal of this study is to evaluate the physiological tolerances underlying the observed patterns of $Z$. japonica distribution, and predict the potential for expansion of this species to additional areas within its established range as well as outside the limits of its current range on the Pacific Coast of North America. The objectives of this study were to compare and contrast the photosynthetic responses of two Z. japonica populations located near the northern and southern limits of distribution for this species, across the range of salinities experienced within estuaries of the American Pacific Northwest. Experiments conducted at the boundaries of species' distribution are critical to understanding factors limiting the spread of introduced species (Byers et al., 2002).

\section{Description of study areas}

\subsection{Padilla Bay, Washington}

Padilla Bay is a relatively shallow, sheltered embayment located in northern Puget Sound, along the mainland coast of Washington. Tides are mixed semidiurnal, with a maximum tidal range of about $4 \mathrm{~m}$ (Bulthuis, 1995). Salinity ranges from 21 to 30, depending on freshwater inflow from the Fraser, Skagit, and Samish Rivers (Bulthuis, 1995). Padilla Bay has one of the largest seagrass areas in the Pacific Northwest (Bulthuis, 1995), representing about 16\% of the total within the Puget Sound region (Wyllie-Echeverria and Ackerman, 2003). In 1989, Padilla Bay contained approximately 2900 ha of intertidal and subtidal Z. marina beds, 324 ha of intertidal Z. japonica, and 137 ha of Ruppia maritima (Bulthuis,
1995). Z. japonica occurs within an elevation range of $+0.1 \mathrm{~m}$ to $+0.8 \mathrm{~m}$, relative to mean lower low water (MLLW) (Thom, 1990). $Z$. japonica samples used in this experiment were collected from the northern portion of Padilla Bay, on the south side of Samish Island (48.574657N lat., $122.538577 \mathrm{~W}$ long.).

\subsection{Coos Bay, Oregon}

Coos Bay is a tidally dominated, deep draft, drowned river valley estuary located along the central Oregon coast. The system has mixed semidiurnal tides and a maximum tidal range of about $2 \mathrm{~m}$ (Lee and Brown, 2009). Salinity ranges between about 20 and 30 depending on freshwater inflow and site within the estuary (Lee and Brown, 2009). As of 2003, Coos Bay contained about 500 ha of $Z$. marina (Thom et al., 2003), Z. japonica is known to be present (Posey, 1988; Shafer, 2007) but its areal extent has not been summarized. Z. japonica specimens for this experiment were collected from a bed near Day Creek inlet, a tidal creek in the South Slough National Estuarine Research Reserve (NERR) at Coos Bay (43.316181N lat., 124.311290W long.). At the time of collection at low tide, salinity in the creek was measured at 0 using a refractometer. Thus, we expect that this population is subject to rapid daily fluctuations in salinity associated with tidal cycles.

\section{Methods}

\subsection{Plant collections and experimental treatments}

The effects of salinity on the photosynthesis-irradiance ( $P$ vs. $E$ ) relationships of these two populations of $Z$. japonica were assessed in the laboratory using a Hansatech liquid-phase oxygen electrode system (Oxylab controller with DW3 chamber, Hansatech Instruments Ltd., Norfolk, England) across a range of salinities that may be experienced by plants along the estuarine salinity gradient. Using a hand trowel, $10 \mathrm{~cm}$ sediment plugs containing intact plants with root material were harvested at low tide from intertidal beds of $Z$. japonica. Thirty plugs were harvested from Padilla Bay, Washington, transported to the laboratory facility at Newport, Oregon, and placed in white polycarbonate tanks $(60 \mathrm{~cm} \times 60 \mathrm{~cm} \times 90 \mathrm{~cm})$ within $8 \mathrm{~h}$ of collection. Each tank was supplied with $>400 \mu \mathrm{mol}$ photons $\mathrm{m}^{-2} \mathrm{~s}^{-1}$ from $1000 \mathrm{~W}$ metal halide lamps on a 14:10 L:D cycle. All three tanks were maintained at a temperature of $25 \pm 2{ }^{\circ} \mathrm{C}$ using submersible aquarium heaters. Similarly, 30 plugs were collected near Day Creek Inlet in Coos Bay, Oregon and randomly assigned to treatment tanks within $4 \mathrm{~h}$ of collection. Each sample plug contained between 10 and 30 Z. japonica shoots. Samples were collected during the summer (June) when biomass was expected to be near its seasonal maximum (Thom, 1990; Kaldy, 2006). The photosynthetic temperature optimum for North American populations of Z. japonica is between 20 and $30^{\circ} \mathrm{C}$ (Shafer et al., 2008) and a similar range of $18-23^{\circ} \mathrm{C}$ was reported by Lee et al. (2005) in Korea. Plants were allowed to acclimate at room temperature $\left(25^{\circ} \mathrm{C}\right)$ for $24-48$ h at a salinity of 32 before being adjusted to test salinities (5,20, and 35). Culture media consisted of ambient seawater from Yaquina Bay; salinities were reduced using reverse osmosis water or increased using Red Sea Salts (Red Sea Fish Pharm Inc., Eliat, Israel). Reverse osmosis removes many of the impurities associated with tap water (ions, chlorine, etc.) but retains some nutrients. Initial nutrient concentrations were not measured; however, after 4 days media nitrogen concentrations ranged between $<1$ and $11 \mu \mathrm{M} \mathrm{NO}_{2}+\mathrm{NO}_{3}$ and $1-11 \mu \mathrm{M} \mathrm{NH}_{4}$. After 10 days all nutrient concentrations in all tanks were $<2 \mu \mathrm{M}$. After holding plants at test salinities for 18-19 days, three sub-samples from each population were collected from each of the salinity treatments for $P$ vs. $E$ curves (details below). In order to account for 
any diel variability, curves were run over the course of several days and sampled in a random sequence during the day (between the hours of 08:00 and 16:00). All treatments were continuously bubbled with air to maintain non-limiting $\mathrm{CO}_{2}$ supplies in the culture media.

\subsection{Photosynthetic measurements}

Since photosynthetic rates within each leaf are known to vary from leaf tip to sheath (Enríquez et al., 2002), an effort was made to minimize this potential source of variance by selecting leaf sections from the mid-point of the second youngest leaf on each shoot. These leaf sections were in the range of $1.5-2.0 \mathrm{~cm}$ in length. Each sample was a composite of four to six leaf sections (from the same plant); care was taken to avoid visibly damaged tissue when selecting samples. Length and width measurements were taken for each piece of tissue using digital calipers. Leaf segments were placed in filtered water at the same treatment salinity and temperature $\left(25^{\circ} \mathrm{C}\right)$ and held in the dark for $30 \mathrm{~min}$. Small sections $\left(<3 \mathrm{~cm}^{2}\right)$ of $400 \mu \mathrm{m}$ clear plastic mesh were used to hold multiple pieces of plant tissue in place side by side in order to avoid shading. We verified that the clear plastic mesh had no detectable impact on photon flux density reaching the leaf surface.

$P$ vs. E curves were run using a Hansatech Oxylab ${ }^{\mathrm{TM}}$ liquidphase oxygen electrode system with a DW3 chamber (Hansatech Instruments Ltd., Norfolk, England). This system uses a Clarktype electrode (Delieu and Walker, 1972) located in the floor of the water-jacketed DW3 $(110 \mathrm{~mm} \times 75 \mathrm{~mm} \times 100 \mathrm{~mm})$ reaction chamber. The volume of water in the chamber was $7 \mathrm{ml}$ for each curve. Prior to each run (before introducing plant material), the oxygen concentration of the chamber media was reduced to $0.280 \pm 0.010 \mu \mathrm{mol} \mathrm{O} \mathrm{Om}^{-1}$ by bubbling with $\mathrm{N}_{2}$ gas. The water jacket of the DW3 chamber was attached to a circulating water chiller so that the temperature in the chamber was maintained at $25^{\circ} \mathrm{C}$. An external red LED light source $(640 \mathrm{~nm} \lambda)$ was fitted to a chamber window (LH36/2R light array, Hansatech Instruments Limited, England) and the light levels in the chamber were controlled via the Oxylab software. Light treatments were verified using a LI-COR 1400 with a cosine corrected sensor (LI-COR, Lincoln Nebraska). The sample was placed in the chamber using the support loops on the chamber plunger such that the plant tissue was perpendicular to the light source. The samples were kept in the darkened chamber for 5 min to allow for equilibration, and a $10 \mathrm{~min}$ measurement of dark respiration was made. Following respiration measurements, the samples were sequentially exposed to $5,10,15,60,125,300,750$, and $1000 \mu \mathrm{mol}$ photons $\mathrm{m}^{-2} \mathrm{~s}^{-1}$. The samples were exposed to each light level for $8 \mathrm{~min}$ to reach equilibrium rates of oxygen evolution $\left(\mu \mathrm{mol} \mathrm{ml}{ }^{-1} \mathrm{~min}^{-1}\right)$.

Once the oxygen evolution measurement was completed, the sample was removed from the chamber and further processed for chlorophyll content. Oxygen evolution rates were normalized to the dry weight $\left(\mu \mathrm{mol} \mathrm{O}_{2} \mathrm{gDW}^{-1} \mathrm{~h}^{-1}\right.$ ) and chlorophyll content ( $\mu \mathrm{mol} \mathrm{O}_{2} \mathrm{mg} \mathrm{chl} \mathrm{a}^{-1} \mathrm{~h}^{-1}$ ) of the sample. Photosynthetic parameters normalized to chlorophyll are not discussed here, but are tabulated for comparison to other studies and regression equations are provided for approximate conversions. Dry weight was estimated from the empirical relationship between dry weight and leaf area. Chlorophyll concentrations were determined on the same leaf segments used to determine $P$ vs. $E$ relationships. Leaf segments were extracted in $10 \mathrm{ml}$ of $99.5 \%$ DMSO and incubated $\left(65^{\circ} \mathrm{C}\right)$ in the dark until pigments were fully leached (approximately $3 \mathrm{~h}$ ) into the solvent (Andersen et al., 1991). Absorbance of the pigmented solvent was measured at 663, 649, and $470 \mathrm{~nm}$ using a Shimadzu UV-2101 spectrophotometer (Shimadzu, Kyoto, Japan).

\subsection{Photosynthetic calculations}

Photosynthetic parameters were calculated using the Smith-Talling function (Lederman and Tett, 1981; Henley, 1993). Data were fitted to this function using the Sigma Plot (version 11.0) statistical software package.

Production $=P_{\max }\left(\frac{\alpha E}{\sqrt{P_{\max }^{2}+(\alpha E)^{2}}}\right)+R_{d}$

where $P_{\max }$ is the maximum rate of photosynthesis, $R_{\mathrm{d}}$ is the dark respiration rate, $E$ is the photon flux density ( $\mu \mathrm{mol}$ photons $\mathrm{m}^{-2}$ $\mathrm{s}^{-1}$ ) and $\alpha$ (photosynthetic efficiency) is the initial slope of the photosynthetic curve with units of $\mu \mathrm{mol} \mathrm{O}_{2} \mathrm{gDW}^{-1} \mathrm{~h}^{-1}$ ( $\mu \mathrm{mol}$ photons $\left.\mathrm{m}^{-2} \mathrm{~s}^{-1}\right)^{-1}$. The compensation irradiance $\left(I_{\mathrm{C}}\right)$ represents the light level at which gross photosynthetic production equals respiration (net photosynthesis is zero; Bulthuis, 1987) and was determined by dividing the respiration rate by $\alpha$ (Henley, 1993). The saturation irradiance $\left(I_{\mathrm{k}}\right)$ was determined by dividing $P_{\max }$ by $\alpha$ (Touchette and Burkholder, 2000).

\subsection{Data analysis}

$P_{\max }$ and $R_{\mathrm{d}}$ values were tested for diel patterns (morning values vs. afternoon values) using a non-parametric, Kruskal-Wallis one-way ANOVA on ranks (SigmaPlot v. 11) because the data violated the assumptions of normality and homogeneity of variances required for parametric statistics. Photosynthetic parameters and tissue respiration rates were analyzed using a nested Analysis of Variance (ANOVA), with population nested within salinity (Sokal and Rohlf, 1995). The nested model does not have an interaction effect, thus we were unable to evaluate the potential for interaction between salinity and population. Bonferroni corrected Fisher's Least Significant Difference (LSD) tests were used to evaluate differences among salinity treatments and populations. For all ANOVA results, significance is reported as $p \leq 0.05$.

\section{Results}

\subsection{Diel rhythms}

Preliminary evaluations were made to test for the presence of diel rhythms in $P_{\max }$ and $R_{\mathrm{d}}$ (Fig. 1). One-way ANOVA on ranks indicates that there were no significant differences $(H=1.043, \mathrm{df}=1$, $p=0.307$ ) between median $P_{\max }$ measurements made in the morning and those made in the afternoon. Likewise, there were no significant differences in median $R_{\mathrm{d}}$ values between morning and afternoon $(H=0.00725, \mathrm{df}=1, p=0.932)$. It should be noted that the morning sample size was smaller than the afternoon.

\subsection{Photosynthetic characteristics}

Both populations of $Z$. japonica exhibited typical photosynthesis-irradiance responses across the range of salinities investigated (Fig. 2). The Smith-Talling function fit the data well with $R^{2}$ values ranging between 0.91 and 0.99 (Table 1). The initial slope of the photosynthesis-irradiance curve $(\alpha)$ ranged from 2.2 to 21.4 (Table 1 ). No significant differences in the initial slope of the photosynthesis-irradiance curve could be detected between salinities or among populations within salinities (Table 2).

Both factors, population and salinity, exerted significant effects on light-saturated photosynthetic rates $\left(P_{\max }\right)$ (Table 2$)$. For the northern (Padilla Bay) population, $P_{\max }$ ranged from 192 to $390 \mu \mathrm{mol} \mathrm{O}_{2} \mathrm{gDW}^{-1} \mathrm{~h}^{-1}$; for the southern (Coos Bay) population 

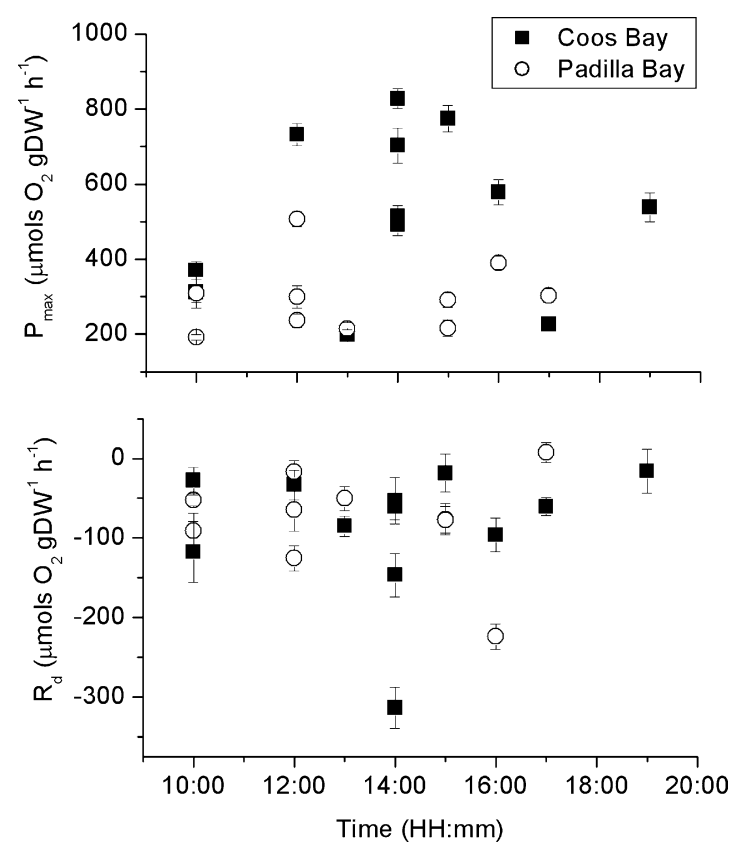

Fig. 1. Zostera japonica maximum rate of photosynthesis $\left(P_{\max }\right)$ and dark respiration rate $\left(R_{\mathrm{d}}\right)$ plotted against time of day. Error bars are standard error from curve fitting and in some cases are smaller than the symbol. Note differences in y-axis scales.

$P_{\text {max }}$ ranged from 226 to $774 \mu \mathrm{mol} \mathrm{O} \mathrm{gDW}^{-1} \mathrm{~h}^{-1}$. For the Coos Bay population, light-saturated photosynthetic rates at a salinity of 5 were significantly lower than at 20 or 35, but light saturated photosynthetic rates at a salinity of 35 were not significantly different from those at a salinity of 20 (Table 3). No differences could be detected among salinity levels in the Padilla Bay population (Table 3).

Whereas saturation irradiance was significantly greater for the southern population than the northern population (Table 2), no significant differences could be detected due to salinity (Table 2). Compensation irradiance $\left(I_{\mathrm{c}}\right)$ was significantly affected

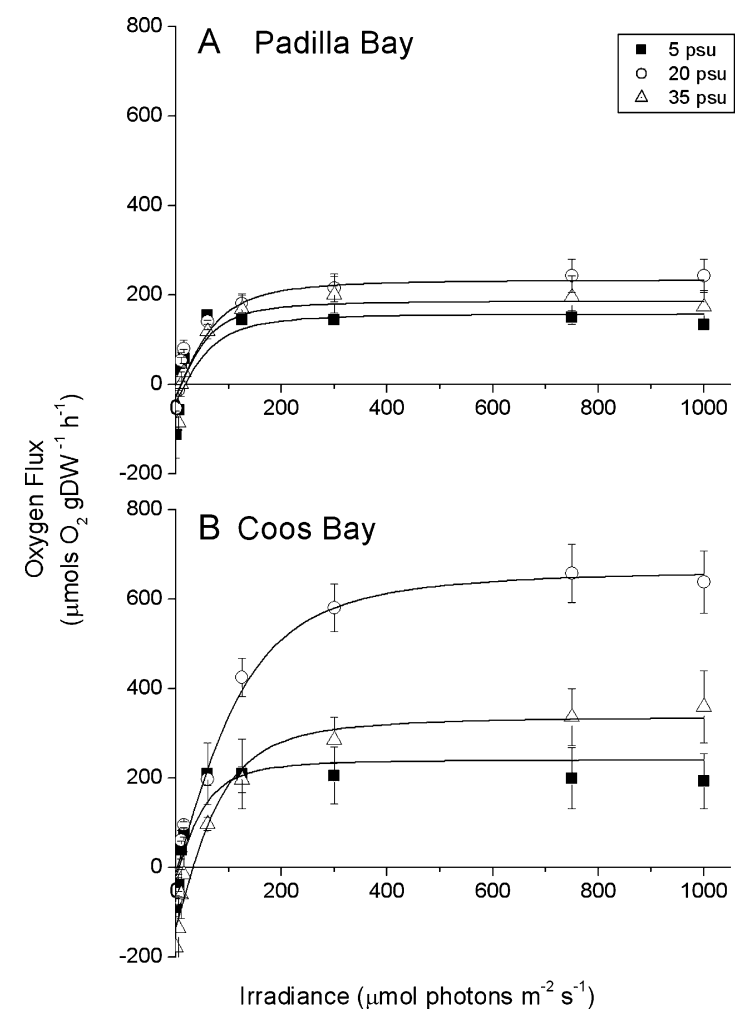

Fig. 2. The effect of salinity on the photosynthesis versus irradiance responses of Zostera japonica collected from Padilla Bay, Washington and Coos Bay, Oregon. Error bars indicate standard error $(n=3)$. Smith-Talling curves were fit iteratively; fit statistics are presented in Table 1.

by salinity (Table 2), and was generally lower at a salinity of 20 than at 5 or 35 (Table 3). The results of the Fisher's LSD multiple comparisons indicated that compensation irradiance at a salinity of 20 was significantly lower than at 5 (Table 3 ). No differences between populations within salinity could be detected (Table 2).

Table 1

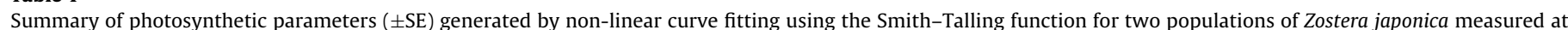

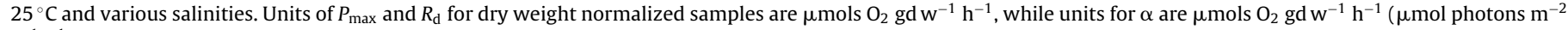

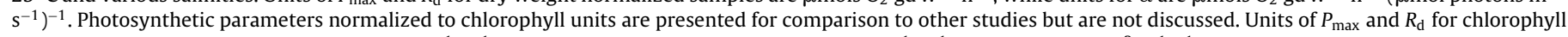
normalized samples are $\mu$ mols $\mathrm{O}_{2} \mathrm{mg} \mathrm{Chl} a+b^{-1} \mathrm{~h}^{-1}$, while units for $\alpha$ are $\mu$ mols $\mathrm{O}_{2} \mathrm{mg} \mathrm{Chl} a+b^{-1} \mathrm{~h}^{-1}\left(\mu \mathrm{mol} \mathrm{photons} \mathrm{m}^{-2} \mathrm{~s}^{-1}\right)^{-1}$.

\begin{tabular}{|c|c|c|c|c|c|c|c|c|c|}
\hline \multirow[t]{2}{*}{ Population } & \multirow[t]{2}{*}{ Plant \# } & \multirow[t]{2}{*}{ Salinity } & \multicolumn{3}{|c|}{ Dry weight normalized } & \multicolumn{4}{|c|}{ Chlorophyll $a+b$ normalized } \\
\hline & & & $P_{\max }$ & $R_{\mathrm{d}}$ & $\alpha$ & $P_{\max }$ & $R_{\mathrm{d}}$ & $\alpha$ & $R^{2}$ \\
\hline Padilla & A048 & 5 & $192(7)$ & $-53(7)$ & $11(1)$ & $18(1)$ & $-5(1)$ & $1.0(0)$ & 0.9925 \\
\hline Padilla & A088 & 5 & $216(22)$ & $-76(20)$ & $17(5)$ & $15(2)$ & $-5(1)$ & $1.2(0)$ & 0.9487 \\
\hline Padilla & A080 & 5 & $390(18)$ & $-224(16)$ & $21(3)$ & $30(1)$ & $-17(1)$ & $1.7(0)$ & 0.9897 \\
\hline Padilla & A069 & 20 & $214(17)$ & $-50(15)$ & $8(2)$ & $36(3)$ & $-8(3)$ & $1.3(0)$ & 0.9707 \\
\hline Padilla & A050 & 20 & $302(19)$ & $8(13)$ & $2(0)$ & $34(2)$ & $1(1)$ & $0.2(0)$ & 0.9786 \\
\hline Padilla & A056 & 20 & $309(24)$ & $-91(22)$ & $17(4)$ & $37(3)$ & $-11(3)$ & $2.1(0)$ & 0.9696 \\
\hline Padilla & D066 & 35 & $291(20)$ & $-77(17)$ & $6(1)$ & $17(1)$ & $-5(1)$ & $0.3(0)$ & 0.9744 \\
\hline Padilla & A095 & 35 & $299(30)$ & $-65(27)$ & $8(3)$ & $19(2)$ & $-4(2)$ & $0.5(0)$ & 0.9492 \\
\hline Padilla & A083 & 35 & 237 (18) & $-126(16)$ & $8(2)$ & $18(1)$ & $-10(1)$ & $0.6(0)$ & 0.9725 \\
\hline Coos & D094 & 5 & $226(12)$ & $-61(11)$ & $13(2)$ & $20(1)$ & $-5(1)$ & $1.2(0)$ & 0.9846 \\
\hline Coos & D088 & 5 & $492(30)$ & $-147(27)$ & $17(4)$ & $121(7)$ & $-36(7)$ & $4.2(1)$ & 0.9817 \\
\hline Coos & D096 & 5 & $312(42)$ & $-118(38)$ & $21(7)$ & $43(6)$ & $-16(5)$ & $2.8(1)$ & 0.9144 \\
\hline Coos & E096 & 20 & $774(35)$ & $-18(24)$ & $5(1)$ & $85(4)$ & $-2(3)$ & $0.6(0)$ & 0.9880 \\
\hline Coos & D069 & 20 & $538(38)$ & $-16(27)$ & $5(1)$ & $51(4)$ & $-2(3)$ & $0.5(0)$ & 0.9711 \\
\hline Coos & D085 & 20 & 732 (29) & $-33(19)$ & $4(1)$ & $80(3)$ & $-4(2)$ & $0.4(0)$ & 0.9910 \\
\hline Coos & C097 & 35 & $370(23)$ & $-28(17)$ & $3(1)$ & $20(1)$ & $-2(1)$ & $0.2(0)$ & 0.9772 \\
\hline Coos & C092 & 35 & $578(34)$ & $-96(21)$ & $3(1)$ & $62(4)$ & $-10(2)$ & $0.3(0)$ & 0.9810 \\
\hline Coos & D067 & 35 & $514(29)$ & $-314(26)$ & $13(3)$ & $48(3)$ & $-29(2)$ & $1.2(0)$ & 0.9835 \\
\hline
\end{tabular}

Biomass normalized parameters can be converted to chl normalized values using the following equations: $P_{\mathrm{m}}=0.125 \times-6.694, n=18, r=0.766, p \ll 0.0001$.

$R_{\mathrm{d}}=0.100 \times-0.601, n=18, r=0.814, p<0.0001$.

$\alpha=0.130 \times-0.187, n=18, r=0.790, p<0.0001$. 
Table 2

Results of nested ANOVAs evaluating the effects of salinity and population nested within salinity on the initial slope of the photosynthesis-irradiance curve $(\alpha)$, compensation irradiance $\left(I_{\mathrm{c}}\right)$, light-saturated photosynthetic rates $\left(P_{\max }\right)$, saturation irradiance $\left(I_{\mathrm{K}}\right)$, and dark respiration rates $\left(R_{\mathrm{d}}\right)$. Bold values are significant at $p<0.05$.

\begin{tabular}{llllll}
\hline Dependent & Factor & DF & SS & $F$ & Prob $>F$ \\
\hline$P_{\max }$ & Salinity & 2 & 131,394 & 3.87 & $\mathbf{0 . 0 4 7}$ \\
& Pop (Sal) & 3 & 400,500 & 7.88 & $\mathbf{0 . 0 0 3}$ \\
$R_{\mathrm{d}}$ & & & & & \\
& Salinity & 2 & 17,587 & 3.86 & $\mathbf{0 . 0 4 8}$ \\
& Pop (Sal) & 3 & 2637 & 0.386 & 0.726 \\
$\alpha$ & & & & & \\
& Salinity & 2 & 29.872 & 2.07 & 0.164 \\
& Pop (Sal) & 3 & 5.00 & 0.232 & 0.872 \\
$I_{\mathrm{C}}$ & & & & & \\
& Salinity & 2 & 216.55 & 4.026 & $\mathbf{0 . 0 4 3}$ \\
& Pop (Sal) & 3 & 21.73 & 0.269 & 0.846 \\
$I_{\mathrm{k}}$ & Salinity & 2 & 875.63 & 1.638 & 0.232 \\
& Pop (Sal) & 3 & 4449.4 & 5.549 & $\mathbf{0 . 0 1 1}$ \\
\hline
\end{tabular}

\subsection{Respiration rates}

Differences in leaf tissue respiration rates among salinity treatments were significant (Table 2). The lowest rates of leaf tissue

Table 3

Summary of Bonferroni corrected Fisher's Least Significant Difference post hoc tests conducted for the nested ANOVA on photosynthetic parameters. Contrasts were performed for each population (salinity) nested combination; separate contrasts were performed for the main salinity effect. For each dependent variable, levels not connected by the same letter are significantly different at $p<0.05$.

\begin{tabular}{|c|c|c|c|c|}
\hline Dependent & Source & Level & $\mathrm{LS}$ mean $\pm \mathrm{SE}$ & \\
\hline \multirow[t]{9}{*}{$P_{\max }$} & Salinity & 5 & $286 \pm 50$ & $\mathrm{~b}$ \\
\hline & & 20 & $478 \pm 53$ & $\mathrm{a}$ \\
\hline & & 35 & $433 \pm 53$ & $a b$ \\
\hline & Pop (Sal) & Padilla (5) & $266 \pm 75$ & c \\
\hline & & $\operatorname{Coos}(5)$ & $307 \pm 65$ & c \\
\hline & & Padilla (20) & $275 \pm 75$ & c \\
\hline & & $\operatorname{Coos}(20)$ & $681 \pm 75$ & d \\
\hline & & Padilla (35) & $275 \pm 75$ & $\mathrm{c}$ \\
\hline & & Coos (35) & $592 \pm 75$ & d \\
\hline \multirow[t]{9}{*}{$R_{\mathrm{d}}$} & Salinity & 5 & $-110 \pm 18$ & $\mathrm{~b}$ \\
\hline & & 20 & $-36 \pm 19$ & $\mathrm{a}$ \\
\hline & & 35 & $-75 \pm 19$ & $a b$ \\
\hline & Pop (Sal) & Padilla (5) & $-117 \pm 27$ & c \\
\hline & & $\operatorname{Coos}(5)$ & $-102 \pm 23$ & c \\
\hline & & Padilla (20) & $-49 \pm 27$ & $\mathrm{~cd}$ \\
\hline & & $\operatorname{Coos}(20)$ & $-22 \pm 27$ & $\mathrm{~d}$ \\
\hline & & Padilla (35) & $-89 \pm 27$ & cd \\
\hline & & $\operatorname{Coos}(35)$ & $-61 \pm 27$ & $\mathrm{~cd}$ \\
\hline \multirow[t]{9}{*}{$I_{\mathrm{c}}$} & Salinity & 5 & $11 \pm 2$ & $\mathrm{a}$ \\
\hline & & 20 & $2.7 \pm 2.1$ & $\mathrm{~b}$ \\
\hline & & 35 & $7.6 \pm 2.1$ & $a b$ \\
\hline & Pop (Sal) & Padilla (5) & $11 \pm 3$ & d \\
\hline & & $\operatorname{Coos}(5)$ & $10 \pm 2$ & $\mathrm{~cd}$ \\
\hline & & Padilla (20) & $3.3 \pm 3$ & $\mathrm{~cd}$ \\
\hline & & Coos (20) & $2 \pm 3$ & c \\
\hline & & Padilla (35) & $9.3 \pm 3$ & $\mathrm{~cd}$ \\
\hline & & Coos (35) & $6 \pm 3$ & $\mathrm{~cd}$ \\
\hline \multirow[t]{9}{*}{$I_{\mathrm{k}}$} & Salinity & 5 & $28.9 \pm 6.2$ & $\mathrm{a}$ \\
\hline & & 20 & $43.7 \pm 6.7$ & $\mathrm{~b}$ \\
\hline & & 35 & $42.3 \pm 6.7$ & $\mathrm{~b}$ \\
\hline & Pop (Sal) & Padilla (5) & $26.4 \pm 9.4$ & d \\
\hline & & $\operatorname{Coos}(5)$ & $31.3 \pm 8.2$ & $\mathrm{~cd}$ \\
\hline & & Padilla (20) & $21.4 \pm 9.4$ & d \\
\hline & & $\operatorname{Coos}(20)$ & $66.1 \pm 9.4$ & $\mathrm{e}$ \\
\hline & & Padilla (35) & $26.9 \pm 9.4$ & d \\
\hline & & $\operatorname{Coos}(35)$ & $57.6 \pm 9.4$ & ce \\
\hline
\end{tabular}

respiration were observed at a salinity of 20 (Table 3). Respiration rates at a salinity of 5 were significantly more negative than at higher salinity (Table 3). Whereas significant differences between populations, within each salinity, could not be detected (Table 2), leaf respiration rates in the Padilla Bay population were generally more negative than those in the Coos Bay population (Table 3 ).

\section{Discussion}

We examined long-term photosynthetic responses to chronic lowering of salinity, such as might be encountered in estuaries or lagoons subject to extreme flooding conditions or altered hydrology. The Coos Bay (southern) Z. japonica population, collected in a tidal creek with freshwater inflows, was exposed to rapidly changing salinities (including zero) on a daily basis, whereas the Padilla Bay (northern) population was exposed to more stable salinity conditions ranging from 22 to 30 . We expected that the stenohaline Padilla Bay population would be more sensitive to osmotic stress than the more euryhaline Coos Bay population.

Our data indicate that North American populations of $Z$. japonica photosynthetic characteristics are best adapted to intermediate salinities, displaying minimum respiration rates, lower compensation irradiance, higher saturation irradiance, and greater light-saturated photosynthetic rates at a salinity of 20 . Thus, $Z$. japonica can also be considered a euryhaline species, tolerating long-term exposure to estuarine salinities in the range of 5-35. Some populations are also capable of tolerating short-term in situ exposure to zero salinity (e.g. Day Creek Inlet, Coos Bay, and Winant Slough, Yaquina Bay, Oregon). The lack of significant differences in photosynthetic efficiency, compensation irradiance, and dark respiration rates between the Padilla and Coos Bay populations suggests that these parameters are unaffected by latitudinal gradients or previous exposure to fluctuating salinity.

Seagrasses have been shown to exhibit a variety of mechanisms for acclimating to salinity fluctuations that range from changes in the cellular ion concentrations (organic osmolytes) to the elasticity of the cell wall (reviewed by Touchette, 2007). Cellular osmotic adjustments of ion concentrations occur in both vacuoles and the cytoplasm via a variety of mechanisms on time scales ranging from hours to days or weeks (Murphy et al., 2003; Touchette, 2007). In a time series experiment, $Z$. marina tended toward an osmotic equilibrium within 4 days in response to sustained salinity changes (Van Diggelen et al., 1987). Over the short-term, salinity response involves osmotic adjustments of inorganic ions and organic osmolytes such as proline, carbohydrates, and organic acids (Touchette, 2007). Most experiments on seagrass photosynthetic response to salinity tend to be short-term on the scale of hours to days. $R$. maritima exhibits decreased quantum yields indicating photosynthetic stress in response to short term salinity changes, but it can physiologically adjust after several days of chronic exposure (Murphy et al., 2003). Chronic salinity reduction over the course of several weeks should allow the Z. japonica plants to adapt to low salinity and reach a physiological equilibrium with respect to photosynthetic characteristics. We suggest that the Padilla Bay and Coos Bay populations may not have developed different tolerances to salinity variations despite inhabiting systems with very different salinity characteristics (stenohaline versus euryhaline). Thus, salinity may not be a strong selective force for this species.

Several studies have concluded that some seagrass species do exhibit diel patterns with high photosynthetic rates (or efficiencies) during the morning and lower rates during the afternoon (Libes, 1986; Durako and Kunzelman, 2002; Silva and Santos, 2003), we found no evidence of this in the two Z. japonica populations examined. The unrecognized presence of diel rhythms could 
confound interpretation of seagrass photosynthetic parameters; testing for diel rhythms should be a routine part of photosynthetic investigations.

Although direct comparisons are sometimes difficult due to the variety of methods and metrics used, there appear to be no consistent patterns in seagrass photosynthetic responses across the salinity gradient. Touchette (2007) suggests that although both photosynthesis and respiration are often inhibited by extreme hypo or hyperosmotic conditions, the degree of inhibition is dependent on the acclimation period. We found that photosynthetic efficiency was relatively unaffected by long-term exposure to salinities ranging from 5 to 35 . In contrast, photosynthetic efficiency of the seagrass Halophila johnsonii Eiseman was reported to increase linearly with increasing salinity, within the range of 0-40 (Torquemada et al., 2005). However, their study was designed to assess short-term salinity responses (1-20 h), whereas in our experimental design the plants were exposed to constant salinity treatments over a period of weeks. Likewise, saturation irradiance also appeared to be unaffected by differences in salinity.

The range of values for compensation irradiance $\left(I_{C}\right)(3-33 \mu \mathrm{mol}$ photons $\left.\mathrm{m}^{-2} \mathrm{~s}^{-1}\right)$ and saturating irradiance $\left(I_{\mathrm{k}}\right)(13-199 \mu \mathrm{mol}$ photons $\mathrm{m}^{-2} \mathrm{~s}^{-1}$ ) observed for Z. japonica in this study were generally lower than those reported for other Zostera species (Touchette and Burkholder, 2000). This may be related to examination of tissue segments as opposed to whole plant incubations. $Z$. japonica compensation irradiance varied significantly within the range of salinities tested, with a minimum at a salinity of 20 , and higher values at 5 and 35. In $H$. johnsonii, compensation irradiance was highest at zero salinity, and decreased with increasing salinity in the range of 0-50 (Torquemada et al., 2005).

Maximum light saturated photosynthetic rates for the southern $Z$. japonica population occurred at a salinity of 20 . Similar results were reported for a Japanese population of $Z$. japonica; highest photosynthetic rates occurred at 3/4 strength and full-strength seawater, with markedly lower rates at both higher and lower salinities (Ogata and Matsui, 1965). Z. marina also exhibits maximum light saturated photosynthetic rates at a salinity of 20 , with lower rates at both higher (25-35) and lower (5-10) salinities (Nejrup and Pedersen, 2008; Kaldy, unpublished data). Additionally, Kamermans et al. (1999) found that Z. marina production and PSII quantum efficiency were higher at a salinity of 22 than at 32 . Some seagrass species (e.g. Zostera muelleri Irmisch ex Aschers. and H. johnsonii) exhibit photosynthetic maxima at higher salinities typical of oceanic seawater (Kerr and Strother, 1985; Torquemada et al., 2005). Other studies reported no relationship between Halodule wrightii Aschers. light saturated photosynthetic rates and salinity along an estuarine gradient (Dunton and Tomasko, 1994; Dunton, 1996).

The lowest respiration rates in $Z$. japonica were observed at a salinity of 20, with increased respiration rates at low (5) and high (35) salinities. Respiration rates of $Z$. muelleri, another intertidal species, were lowest at full-strength seawater, and approximately twice as great at $50 \%$ seawater salinity than at $100 \%$ seawater salinity (Kerr and Strother, 1985). In contrast, Z. marina respiration rates are reported to be relatively insensitive to changes in salinity ranging from zero (distilled water) to $2 \times$ and $3 \times$ seawater solutions (Biebl and McRoy, 1971; Hellblom and Björk, 1999; Kaldy, unpublished data).

Stands of Z. japonica located along the central and southern Oregon coast (Yaquina and Coos Bay) appear to be capable of more rapid growth and photosynthesis rates than northern populations (Padilla Bay, Washington; Shafer et al., 2008; this study). Southern stands are also more tolerant of warmer temperatures and become light-saturated at higher irradiances than the northern stand (Shafer et al., 2008; this study). Whether these differences results from variations in acclimation to local environmental conditions or have an underlying genetic basis is unknown. However, this body of evidence does suggest that southern stands may possess greater photosynthetic physiological tolerance, which may increase the potential for further expansion southward along the Pacific Coast and changes associated with global climate change.

\section{Acknowledgements}

The authors wish to thank the Smith and Down's families of Samish Island and D. Bulthuis at the Padilla Bay NERR for access to the Padilla Bay sampling site and C. Cornu for access to the Coos Bay, South Slough NERR sampling site. M. Hannam, J. Stecher and C. Folger assisted with field collections. Additionally, we wish to thank S. Lynch, M. McCary, S. Hankin, J. Dean and A. McFadden for assistance with culture maintenance and plant measurements. Earlier versions of this manuscript benefited from discussions and comments from T. Nelson, B. Ozretich, W. Nelson, T. Fontaine, $\mathrm{J}$. Vermaat and 2 anonymous reviewers. The information in this document represents a collaborative research effort between the U.S. Environmental Protection Agency and the U.S. Army Corps of Engineer Research and Development Center. It has been subjected to review by the National Health and Environmental Effects Research Laboratory's Western Ecology Division and approved for publication. Approval does not signify that the contents reflect the views of the agency, nor does mention of trade names or commercial products constitute endorsement or recommendation for use.

\section{References}

Andersen, C.P., McLaughlin, D.B., Roy, W.K., 1991. Foliar injury symptoms and pigment concentrations in red spruce sapling in the southern Appalachians. Can. J. Forest Res. 21, 1119-1123.

Baldwin, J.R., Lovvorn, J.R., 1994. Expansion of seagrass habitat by the exotic Zostera japonica and its use by dabbling ducks and brant in Boundary Bay British Columbia. Mar. Ecol. Prog. Ser. 103, 119-127.

Bando, K.J., 2006. The roles of competition and disturbance in a marine invasion. Biol. Inv. 8, 755-763.

Biebl, R., McRoy, C.P., 1971. Plasmatic resistance and rate of respiration and photosynthesis of Zostera marina at different salinities and temperatures. Mar. Biol. 8, 48-56.

Bulthuis, D.A., 1987. Effects of temperature on photosynthesis and growth of seagrasses. Aquat. Bot. 27, 27-40.

Bulthuis, D.A., 1995. Distribution of seagrasses in a North Puget Sound estuary: Padilla Bay, Washington, USA. Aquat. Bot. 50, 99-105.

Byers, J.E., Reichard, S., Randall, J.M., Parker, I.M., Smith, C.S., Lonsdale, W.M., Atkinson, I.A.E., Seastedt, T.R., Williamson, M., Chornesky, E., Hayes, D., 2002. Directing research to reduce the impacts of nonindigenous species. Conserv. Biol. 16, 630-640.

Delieu, T.D., Walker, D.A., 1972. A improved cathode for the measurement of photosynthetic oxygen evolution by isolated chloroplasts. New Phytol. 71, 201-205.

Den Hartog, C., 1970. The Sea-grasses of the World. North-Holland Publishing Company, Amsterdam, Netherlands.

Dudoit, C.M., 2006. The distribution and abundance of a non-native eelgrass, Zostera japonica, in Oregon estuaries. B.S. Senior Thesis. Oregon State University, Corvallis, OR. http://ir.library.oregonstate.edu/jspui/handle/1957/5055

Dumbauld, B.R., Wyllie-Echeverria, S., 2003. The influence of burrowing thalassinid shrimps on the distribution of intertidal seagrasses in Willapa Bay, Washington, USA. Aquat. Bot. 77, 27-42.

Dunton, K.H., 1996. Photosynthetic production and biomass of the subtropical seagrass Halodule wrightii along an estuarine gradient. Estuaries 19, 436-447.

Dunton, K.H., Tomasko, D.A., 1994. In situ photosynthesis in the seagrass Halodule wrightii in a hypersaline subtropical lagoon. Mar. Ecol. Prog. Ser. 107, 281-293.

Durako, M.J., Kunzelman, J.I., 2002. Photosynthetic characteristics of Thalassia testudinum measured in situ by pulse-amplitude modulated (PAM) fluorometry: methodological and scale-based considerations. Aquat. Bot. 73, 173-185.

Enríquez, S., Merino, M., Iglesias-Prieto, R., 2002. Variations in the photosynthetic performance along the leaves of the tropical seagrass Thalassia testudinum. Mar. Biol. 140, 891-900.

Green, E.P., Short, F.T., 2003. World Atlas of Seagrasses. University of California Press, Berkeley, CA.

Harrison, P.G., Bigley, R.E., 1982. The recent introduction of the seagrass Zostera japonica Aschers \& Graebn to the Pacific coast of North America. Can. J. Fish. Aq. Sci. 39, 1642-1648. 
Hellblom, F., Björk, M., 1999. Photosynthetic responses in Zostera marina to decreasing salinity, inorganic carbon content and osmolality. Aquat. Bot. 65, 97-104.

Henley, W.J., 1993. Measurement and interpretation of photosynthetic light response curves in algae in the context of photoinhibition and diel changes. J. Phycol. 29, 729-739.

Hitchcock, C.L., Cronquist, A., Ownbey, M., Thompson, J.W., 1969. Vascular Plants of the Pacific Northwest. Part I: Vascular Cryptograms, Gymnosperms, and Monocotyledons. University of Washington Press, Seattle, WA

Huong, T.T.L., Vermaat, J.E., Terrados, J., Tien, N.V., Duarte, C.M., Borum, J., Tri, N.H., 2003. Seasonality and depth zonation of intertidal Halophila ovalis and Zostera japonica in Ha Long Bay (northern Vietnam). Aquat. Bot. 75, 147-157.

Jiménez, C., Niell, F.C., Algarra, P., 1987. Photosynthetic adaptation of Zostera noltii Hornem. Aquat. Bot. 29, 217-226.

Kaldy, J.E., 2006. Production ecology of the non-indigenous seagrass, dwarf eelgrass (Zostera japonica Ascher \& Graeb.) in a Pacific Northwest estuary, USA. Hydrobiologia 553, 201-217.

Kamermans, P., Hemminga, M.A., de Jong, D.J., 1999. Significance of salinity and silicon levels for growth of a formerly estuarine eelgrass (Zostera marina) population (Lake Grevelingen, The Netherlands). Mar. Biol. 133, 527-539.

Kerr, E.A., Strother, S., 1985. Effects of irradiance, temperature and salinity on photosynthesis of Zostera muelleri. Aquat. Bot. 23, 177-183.

Lederman, T.C., Tett, P., 1981. Problems in modelling the photosynthesis-light relationships for phytoplankton. Bot. Mar. 24, 125-134.

Lee, S.Y., Oh, J.H., Choi, C.I., Suh, Y., Mukai, H., 2005. Leaf growth and population dynamics of intertidal Zostera japonica on the western coast of Korea. Aquat. Bot. 83, 263-280.

Lee II, H., Brown, C.A. (Eds.), 2009. Classification of Regional Patterns of Environmental Drivers and Benthic Habitats in Pacific Northwest Estuaries. U.S. EPA Office of Research and Development, National Health and Environmental Effects Research Laboratory, Western Ecology Division, EPA/600/R-09/140.

Libes, M., 1986. Productivity-irradiance relationship of Posidonia oceanica and its epiphytes. Aquat. Bot. 26, 285-306.

Murphy, L.R., Kinsey, S.T., Durako, M.J., 2003. Physiological effects of short-term salinity changes on Ruppia maritima. Aquat. Bot. 75, 293-309.

Nejrup, L.B., Pedersen, M.F., 2008. Effects of salinity and water temperature on the ecological performance of Zostera marina. Aquat. Bot. 88, 239-246.

Ogata, E., Matsui, T., 1965. Photosynthesis of several marine plants of Japan as affected by salinity, drying and $\mathrm{pH}$, with attention to their growth habits. Bot Mar. 8, 199-217.

Posey, M.H., 1988. Community changes associated with the spread of an introduced seagrass, Zostera japonica. Ecology 69, 974-983.

Plus, M., Auby, I., Verlaque, M., Levavasseur, G., 2005. Seasonal variations in photosynthetic irradiance response curves of macrophytes from a Mediterranean coastal lagoon. Aquat. Bot. 81, 157-173.
Ralph, P.J., 1998. Photosynthetic responses of Halophila ovalis (R Br.) Hook. f. to osmotic stress. J. Exp. Mar. Biol. Ecol. 227, 203-220.

Shafer, D., Wyllie-Echeverria, S., Sherman, T., 2008. The potential role of climate in the distribution of the introduced seagrass Zostera japonica in North America. Aquat. Bot. 89, 297-302.

Shafer, D.J., 2007. Physiological factors affecting the distribution of the nonindigenous seagrass Zostera japonica along the Pacific Coast of North America. Ph.D. Dissertation. University of South Alabama, Mobile, AL.

Silva, J., Santos, R., 2003. Daily variation patterns in seagrass photosynthesis along a vertical gradient. Mar. Ecol. Prog. Ser. 257, 37-44.

Sokal, R.R., Rohlf, F.J., 1995. The Principles and Practice of Statistics in Biological Research. Freeman and Company, New York.

Thom, R.M., 1990. Spatial and temporal patterns in plant standing stock and primary production in a temperate seagrass system. Bot. Mar. 33, 497-511.

Thom, R.M., Borde, A.B., Rumrill, S., Woodruff, D.L., Williams, G.D., Southard, J.A., Sargeant, S.L., 2003. Factors influencing spatial and annual variability in eelgrass (Zostera marina L.) meadows in Willipa Bay, Washington and Coos Bay, Oregon, estuaries. Estuaries 26, 1117-1129.

Torquemada, Y.F., Durako, M.J., Lizaso, J.L.S., 2005. Effects of salinity and possible interactions with temperature and $\mathrm{pH}$ on growth and photosynthesis of Halophila johnsonii Eiseman. Mar. Biol. 148, 251-260.

Touchette, B.W., 2007. Seagrass-salinity interactions: physiological mechanisms used by submersed marine angiosperms for a life at sea. J. Exp. Mar. Biol. Ecol. 350, 194-215.

Touchette, B.W., Burkholder, J.M., 2000. Overview of the physiological ecology of carbon metabolism in seagrasses. J. Exp. Mar. Biol. Ecol. 250, 169-205.

Tyerman, S.D., 1982. Water relations of seagrasses. Plant Physiol. 69, 957965.

Van Diggelen, J., Rozema, J., Broekman, R., 1987. Mineral composition of and proline accumulation by Zostera marina $\mathrm{L}$. in response to environmental salinity. Aquat. Bot. 27, 169-176.

Vermaat, J.E., Verhagen, F.C.A., Lindenburg, D., 2000. Contrasting responses in two populations of Zostera noltii Hornem. to experimental photoperiod manipulation at two salinities. Aquat. Bot. 67, 179-189.

Vermaat, J.E., Verhagen, F.C.A., 1996. Seasonal variation in the intertidal seagrass Zostera noltii Hornem.: coupling demographic and physiological patterns. Aquat. Bot. 52, 259-281.

Wyllie-Echeverria, S., Ackerman, J.D., 2003. The seagrasses of the Pacific Coast of North America. In: Green, E.P., Short, F.T. (Eds.), World Atlas of Seagrasses. University of California Press, Berkeley, USA, pp. 199-206.

Young, D.R., Clinton, P.J., Specht, D.T., DeWitt, T.H., Lee, I.I.H., 2008. Monitoring the expanding distribution of nonindigenous dwarf eelgrass Zostera japonica in a Pacific Northwest USA estuary using high resolution digital aerial orthophotography. J. Spatial Sci. 53, 87-97. 